Article

\title{
Assessment of Chitosan-Rue (Ruta graveolens L.) Essential Oil-Based Coatings on Refrigerated Cape Gooseberry (Physalis peruviana L.) Quality
}

\author{
María González-Locarno ${ }^{1}$, Yarley Maza Pautt ${ }^{1}$, Alberto Albis ${ }^{1}$, Edwin Florez López ${ }^{2}$ \\ and Carlos David Grande Tovar ${ }^{3, *}$ (1) \\ 1 Chemical Engineering Program, Faculty of Engineering, Universidad del Atlántico, Carrera 30 Number 8-49, \\ Puerto Colombia 081008, Colombia; mclaudiagonzalez@mail.uniatlantico.edu.co (M.G.-L.); \\ ymaza@mail.uniatlantico.edu.co (Y.M.P.); albertoalbis@uniatlantico.edu.co (A.A.) \\ 2 Grupo de Investigación en Química y Biotecnología QUIBIO, Universidad Santiago de Cali, Calle 5 No 62-00, \\ Cali 760035, Colombia; edwin.florez00@usc.edu.co \\ 3 Grupo de Investigación de Fotoquímica y Fotobiología, Universidad del Atlántico, Carrera 30 No. 8-49, \\ Puerto Colombia 081008, Colombia \\ * Correspondence: carlosgrande@mail.uniatlantico.edu.co; Tel.: +57-5-3599484
}

Received: 17 March 2020; Accepted: 7 April 2020; Published: 13 April 2020

\begin{abstract}
Cape gooseberry (Physalis peruviana L.) is one of the main exotic fruits in demand throughout the world market. However, this fruit has problems with physical and microbial decay causing losses up to thirty percent during post-harvest stage and market storage. As an alternative for conservation, technologies based on edible coatings of biopolymers incorporating essential oils have been developed. In this paper we studied the effect of edible coatings based on chitosan (CS) and Ruta graveolens L. essential oil (RGEO) at different concentrations applied on the surface gooseberries at $18 \pm 2{ }^{\circ} \mathrm{C}$. The emulsions exhibited a reduction in the viscosity and the particle size with the increasing in the RGEO amount (from $124.7 \mathrm{cP}$ to $26.0 \mathrm{cP}$ for CS + RGEO 0.5\% and CS + RGEO 1.5\%, respectively). A lower weight loss was obtained for fruits coated with CS + RGEO $0.5 \%(12.7 \%)$ as compared to the uncoated $(15 \%)$, while the maturity index increased in a lower amount for CS + RGEO coated than the uncoated fruits. The mesophyll growth was delayed three days after the coating applications for CS + RGEO 1.0\% and 1.5\%. At day twelve of the coating process, fruits with CS + RGEO 1.5\% presented only 3.1 Log UFC/g of aerobic mesophylls and 2.9 Log UFC/g of molds and yeasts, while the uncoated fruits presented $4.2 \mathrm{Log} \mathrm{UFC} / \mathrm{g}$ of aerobic mesophylls and $4.0 \mathrm{Log} \mathrm{UFC} / \mathrm{g}$ of molds and yeasts, demonstrating a microbial barrier of the coatings incorporating RGEO in a concentration dependent manner. The CS + RGEO coating also preserve the antioxidant property of case gooseberries after twelve days of treatment under storage according to the 2,2'-Diphenyl-1-picrylhydrazyl (DPPH) and 2,2'-azinobis-(3-ethyl-benzothiazoline-6-sulphonic acid) (ABTS) results. It was demonstrated by the ABTS method that T5 antioxidant capacity from day one to day twelve only decreases from $55 \%$ to $44 \%$, while in the uncoated fruits (T1) the antioxidant capacity decreased from $65 \%$ to $18 \%$. On the other hand, using the DPPH method the reduction was from $73 \%$ to $24 \%$ for the uncoated samples and $55 \%$ to $43 \%$ for T5. From the sensorial analysis, we recommend the use of CS + RGEO $0.5 \%$ that was still accepted by the panelists after the sixth day of application. These results show the potential application of these coatings as postharvest treatment under storage and low temperature conditions during twelve days of treatment for cape gooseberry fruits.
\end{abstract}

Keywords: antioxidant; antibacterial; chitosan edible coatings; Physalis peruviana; Ruta graveolens essential oil 


\section{Introduction}

Cape gooseberry or goldenberry (Physalis peruviana L.) is one of the leading exotic fruits appreciated in the world market due to its high content of vitamins, fiber, antioxidants, therapeutics, and organoleptic compounds [1]. It is from the Solanaceae family, a fruit native of Peru considered a climacteric fruit, which forms its fruit in an inflated calyx. Usually, calyx and skin color can be used to indicate maturity [2]. Cape gooseberry is highly appreciated for its texture, flavor, and aroma, introducing low calorie content in a rich fiber diet [3].

Colombia is considered one of the leading producers of cape gooseberries in the world, annually exporting $7.2 \times 10^{3}$ tons of cape gooseberries, the second most exported fruit after banana fruit, mainly to European countries [4].

The cape gooseberry fruit is acid-sweet in taste, with a pleasant flavor and typically consumed fresh, whole, or sliced, without the calyx, but with the skin [2]. The fruit is also significant for the preparation of salads, desserts, and different puddings. However, the most considerable consumption is fresh. Nowadays, the goldenberry crops are considered very promising for subtropical areas of the USA [5].

In 2009, the primary consumers of Colombian cape gooseberries were The Netherlands (3200 tons), Germany (1600 tons), Belgium (966 tons), Sweden (214 tons), and France (130 tons). However, Colombia only exported 18.4 tons to the United States as a result of the demanding quarantine cold treatment, where edible coatings to preserve fruits and increase the storage stability under refrigerated conditions could be very useful [6]. Usually, for distribution to the world markets, cape gooseberries are packed in plastic or wood boxes with a capacity of $8 \mathrm{~kg}$ for fruit with a calyx and $10 \mathrm{~kg}$ without a calyx, which means that the present treatment will favor more fruit per box, avoiding a higher plastic consumption around the world [7].

When the calyx is removed from the cape gooseberries, the fruits have higher respiration rates, generating higher levels of ethylene and accelerating their decay, it is not adequately stored [8]. With the ripening process, the fruit colors change from green (chlorophyll) to yellowish-orange (carotenoids) and a softening of the surface, with several cell-wall enzymatic changes [9].

In addition to some contamination during the production stage, goldenberry suffers post-harvest diseases caused by several fungi. For example, in the Maharashtra region of India, Rao, and Subramoniam described a post-harvest disease caused by Fusarium equiseti (Corda) Sacc., entering at points of injuries and bruises on stored berries and subsequently inciting a soft rot [8,10]. In addition, in the fruit market of Aligarh (India), Sharma and Khan isolated on goldenberry the fungi Alternaria alternata (Fr.) Keissler, Cladosporium cladosporioides (Fres.) de Vries, and Penicillium italicum Wehmer, directly affected in storing markets [11].

Usually, for commercialization purposes, the fruits must accomplish quality, nutritional, and healthy characteristics, for client acceptance in the international markets [12]. To meet those requirements, they are treated using chemical products (synthetic fungicides such as iprodione, fludioxonil, and fenhexamid), which due to their excessive use, have generated problems of pollution to the environment, complications in human health, and resistant in microorganisms $[13,14]$.

The natural polymer-based coatings to preserve quality and freshness of fruits should have consumer acceptation without altering the original flavor, appearance, aroma, etc., and it should have biocompatibility, gas barrier properties, non-toxic, non-polluting, good physical appearance, and low average cost [15]. Edible coatings are sprayed or brushed directly on the fruit surface to crate modify atmospheres and a barrier effect without generating anaerobiosis or negatively affect the quality of the fruit. Since the materials will be humanly consumed, they should be based on raw materials, generally referred to as safe (GRAS) [16].

Chitosan is a world-wide abundant and safe polysaccharide, with excellent antimicrobial and biocompatibility properties broadly incorporated in edible coatings and applied on fruit surfaces for preservation purposes [14,17]. However, its hydrophilic nature is a weak moisture barrier that needs to be improved by the development of composites incorporating lipids such as essential oils and fatty 
acids [18]. Therefore, alternatives incorporating hydrophobic compounds to strengthen moisture barrier such as some essential oils, having antioxidant, antibacterial, and antifungal properties that preserve and protect food during the post-harvest of the fruit is an added-value strategy [19].

Carvalho et al. [6] investigate the effect of alginate coating and cold storage on the bioactive compounds present in cape gooseberries [6]. Licodiedoff et al. [20] studied the effect of apply gelatin-calcium chloride on cape gooseberry without Calyx, which provided a reduction of weight loss and fungal deterioration [20]. However, no reports using chitosan-Ruta graveolens essential oil have been investigated for cape gooseberry storage under refrigeration conditions.

The incorporation of Rue essential oil (Ruta graveolens L.) could be an excellent option to complement the antimicrobial activity of chitosan. Ruta graveolens L. essential oil (RGEO) components, such as the 2-undecanone, 2-nonanone, and monoterpenes, have been recognized as antifungal components [21,22]. The incorporation of the RGEO components in the chitosan (CS) matrix improves barrier, antimicrobial, antifungal, and antioxidant properties, as previously demonstrated, especially to control Colletotrichum gloesporioides fungi, which allowed to prolong the stability in guavas harvested in Colombia [23].

In this research, our interest is to evaluate the effect on the physicochemical, antioxidant, and quality properties of cape gooseberries after the CS + RGEO coatings application. To the best of our knowledge, this is the first time that the application of CS + RGEO coatings is reported in cape gooseberries to evaluate the effect in quality aspects of cape gooseberry fruits.

\section{Materials and Methods}

\subsection{Fruit Samples}

Cape gooseberry (P. peruviana L.) fruit with the calyx, Colombian ecotype were selected from a local market of the Colombian city (Tunja), and protected with their natural calyx in a maturation stage four, according to the Colombian Technical Standard (NTC) 4580 [24]. Seven hundred fruits were selected according to the standard, healthy, and with uniform size and color. Subsequently, they were washed with a $100 \mathrm{mg} / \mathrm{L}$ solution of sodium hypochlorite, dried, and stored at a temperature of $18 \pm 2{ }^{\circ} \mathrm{C}$ until their use.

\subsection{Preparation of Edible Coatings}

Emulsions were prepared following a previously reported methodology [23]. Briefly, one liter of a solution of a specific amount of chitosan was prepared (degree of deacetylation $=85 \%$, $\mathrm{Mw}=190.000-310.000 \mathrm{Da}$, Sigma-Aldrich, Palo Alto, California, USA), using a $0.1 \mathrm{M}$ acetic acid a solution ( $\mathrm{pH} 5.6)$ were glycerol $(2.5 \% \mathrm{v} / \mathrm{v})$ was added dropwise under magnetic stirring during $30 \mathrm{~min}$. After that, Tween 80 was added $(1 \% v / v)$ concerning the final volume of RGEO (Krauter, Colombia). RGEO was previously characterized and added to reach final concentrations of $0.5 \%, 1.0 \%$, and $1.5 \%$ $\mathrm{v} / \mathrm{v}$, with respect to the chitosan solution [23]. The final mixture was mixed using an IKA T25-Digital Ultraturrax (Staufen) (USA) at $7000 \mathrm{rpm}$ for two minutes. All the bubbles were removed by vacuum from the emulsions.

\subsection{Application of Edible Coatings to Cape Gooseberries}

Cape gooseberries were coated by direct immersion in the different emulsions. The treatments consisted of one control (T1) and four different treatments (T2 = CS, T3 = CS + RGEO 0.5\%, T4 = CS + RGEO 1.0\%, T5 = CS + RGEO 1.5\%), in glass cells of $15 \mathrm{~cm} \times 9 \mathrm{~cm} \times 12 \mathrm{~cm}$ high with the help of a metal support for five minutes. Subsequently, they were dried for $60 \mathrm{~min}$ at $16^{\circ} \mathrm{C}$ and stored in boxes of ethylene poly terephthalate (PET) under refrigerated conditions $\left(18 \pm 2{ }^{\circ} \mathrm{C}\right)$ for 12 days. 


\subsection{Physicochemical Characterizations of Emulsions}

The particle size, density, viscosity, and non-volatile compounds of the emulsions were determined according to the methodologies reported previously [23,25]. Briefly, the particle size of the emulsions was tested using a laser diffractometer was used (AIMSIZER 2011, Dandong Liaoning, China). The viscosity was determined using a Brookfield LVF (Toronto, Canada) viscometer. Density determination was made based on the parameters established in ISO 8655-2 [26]. The liquid was weighed on an analytical balance (Adventurer AR2140, USA), and the results were expressed according to Equation (1).

$$
\mathrm{d}=\mathrm{P}_{1} / \mathrm{V}_{1}
$$

where $P_{1}$ is the weight of the dosed volume $(\mathrm{g}), \mathrm{V}_{1}$ the volume of dosage $(1 \mathrm{~mL})$, and $\mathrm{d}$ the density of the sample at $25^{\circ} \mathrm{C}(\mathrm{g} / \mathrm{mL})$.

The non-volatile compounds were calculated from Equation (2):

$$
\mathrm{S}(\%)=\left(\left(\mathrm{P}_{\mathrm{S}}-\mathrm{P}_{\mathrm{d}}\right) /\left(\mathrm{P}_{\mathrm{m}}-\mathrm{P}_{\mathrm{d}}\right)\right) \times 100
$$

where, $\% \mathrm{~S}$ is the percentage of non-volatile solids in the sample $(\mathrm{g} / \mathrm{g}), \mathrm{P}_{\mathrm{d}}$, is the weight of the dry and clean aluminum disk $(\mathrm{g}), \mathrm{P}_{\mathrm{m}}$, is the weight of the sample plus the aluminum disk $(\mathrm{g})$, and $\mathrm{P}_{\mathrm{s}}$ is the weight of the dried sample plus the aluminum disk (g).

\subsection{Physical-Chemical Analysis of Cape Gooseberries}

For the physical-chemical tests of the fruits ( $\mathrm{pH}$, soluble solids, titratable acidity, and maturity index analysis), we used the Colombian technical standard (NTC) 4580 parameters [24], for 75 cape gooseberries on days $0,3,6,9$, and 12 according to the next methodologies:

\subsection{1. $\mathrm{pH}$ and Total Soluble Solids (TSS)}

The $\mathrm{pH}$ was determined with a potentiometer Thermo Fisher Scientific Orion (USA) calibrated at three points: 4, 7, and 10. Samples used consisted of five grams of fruit homogenized in $50 \mathrm{~mL}$ of distilled water [27]. The total soluble solids (TSS) ( ${ }^{\circ}$ Brix) were measured with a BRIXCO $0 \%-90 \%$ brand refractometer, previously calibrated with deionized water at a temperature of $20 \pm 1^{\circ} \mathrm{C}$.

\subsubsection{Titratable Acidity}

The acidity was determined using a potentiometric titration [23], until neutral $\mathrm{pH}$. Five grams of fruit were homogenized, with $50 \mathrm{~mL}$ of distilled water. The titration was carried out with $0.1 \mathrm{~N} \mathrm{NaOH}$. The results were expressed in Citric acid percentage, as shown in Equation (3):

$$
\text { Citric Acid }(\%)=\left(\frac{\mathrm{V} 1 \times \mathrm{N}}{\mathrm{V} 2}\right) \times \mathrm{K} \times 100
$$

where, $\mathrm{V}_{1}$ is the volume of $\mathrm{NaOH}$ consumed $(\mathrm{mL}), \mathrm{V}_{2}$ is the volume of sample $(\mathrm{mL}), \mathrm{k}$ is the equivalent weight of citric acid $(0.064 \mathrm{~g} / \mathrm{meq})$, and $\mathrm{N}$ is the normality of $\mathrm{NaOH}(0.1 \mathrm{meq} / \mathrm{mL})$.

\subsubsection{Maturity Index}

It was calculated as the ratio of SST and titratable acidity [28] as shown in Equation (4):

$$
\text { Maturity index }=\frac{\text { SST }(\%)}{\text { Acidity }(\%)}
$$




\subsubsection{Weight Loss}

Weight loss was determined gravimetrically on days 3, 6, 9, and 12 [29], using the Equation (5):

$$
W l(\%)=\frac{(W i-W f)}{W i} \times 100
$$

where $\% W l$ is the percentage of weight loss, and $W i$ and $W f$, are the initial and final weight of each sample (g).

\subsubsection{Damage Index}

It was evaluated visually according to the methodology proposed by Chicaiza Vélez [30] following the visual scale of Figure 1. The scale for decay index consisted in: (1) there is no damage ( $0 \%$ mold growth), (2) mild damage ( $10 \%-15 \%$ mold growth), (3) moderate damage ( $25 \%-50 \%$ mold growth), and (4) Severe damage ( $>50 \%$ mold growth). The results were expressed according to damage levels, using Equation (6):

$$
\text { Decay index }=\frac{1 \mathrm{n}+2 \mathrm{n}+3 \mathrm{n}+4 \mathrm{n}}{\mathrm{N}}
$$

where $\mathrm{n}=$ number of fruits classified in each level of the damage scale and $\mathrm{N}=$ number of total fruits analyzed in each treatment per day. The damage index of fruits was evaluated on days $0,3,6,9$, and 12 .
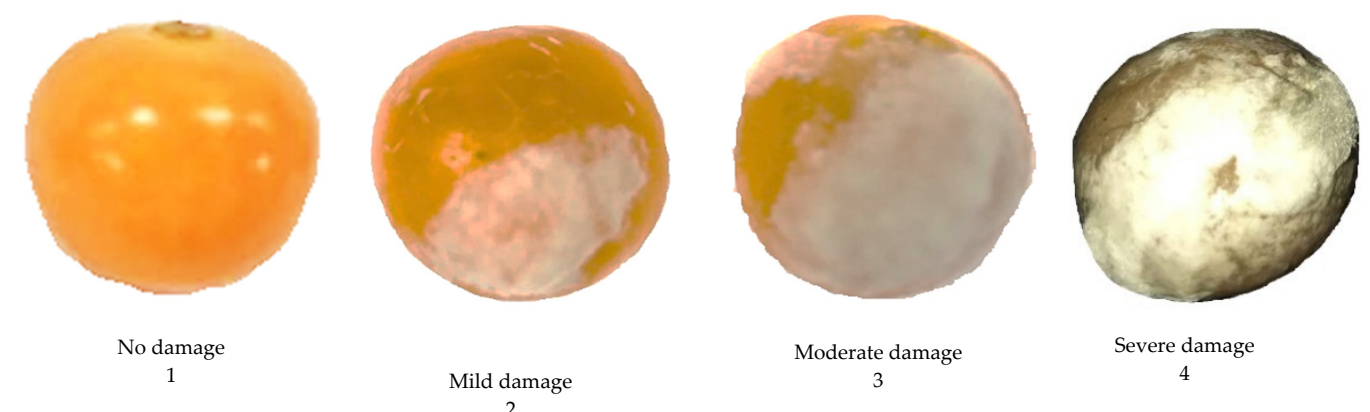

Figure 1. The damage scale of the cape gooseberries.

\subsubsection{Color Index}

The color index (CI) was calculated from CIELab system parameters $\left(\mathrm{L}^{*} \mathrm{a}{ }^{*} \mathrm{~b} *\right.$ ) determined through a digital imaging system using the professional photo editing software Adobe Photoshop ${ }^{\circledR}$ CS5 test version (Adobe System Inc. 2015 Edition) and measured from Equation (7) [31].

$$
\mathrm{CI}(\%)=\left(\frac{1000 \times \mathrm{a} *}{\mathrm{~L} * \times \mathrm{b} *}\right) \times 100
$$

\subsection{Microbiological Activity}

The microorganism count was performed by a duplicate for days $0,3,6,9$, and 12 . Briefly, ten grams of cape gooseberries were weighed and homogenized in $90 \mathrm{~mL}$ of buffered peptone water for $15 \mathrm{~min}$. Then, dilutions of $10^{-1}$ to $10^{-5}$ were prepared, and one milliliter of each dilution was taken for the broths. For the mold and yeast count, NTC 4132 [32] was followed using Potato-glucose agar (PDA) as media with $10 \%$ tartaric acid $(w / v)$, and the plates were incubated at a temperature $25 \pm 0.2{ }^{\circ} \mathrm{C}$ for five days. For the mesophilic aerobic count, the NTC 4092 [33] and ISO 4833-2 [34] standards were followed, using as a culture method Agar Plate Count (PCA); the plates were incubated at a temperature of $30 \pm 1{ }^{\circ} \mathrm{C}$ for three days. 


\subsection{Sensorial Activity}

The test was carried out based on the NTC 3932 [35]. The experiments were performed in the nutrition and dietetics laboratory of the Universidad del Atlántico, with 50 people non-trained panelists. Five groups of ten panelists were used to perform the tests independently, during days 0,3 , and 6 of storage. The groups were informed of the test methodology, additionally signed an informed consent that contained data on the reagents used in the preparation of the emulsions and the risks of exposition.

\subsection{Antioxidant Activity}

Two methods based on radical scavenging (DPPH• and ABTS•+) were used to evaluate the antioxidant activity changes during the storage time of the cape gooseberries.

For the preparation of the methanolic extract, two grams of cape gooseberries treated with CS + RGEO coatings were taken and mixed with $9 \mathrm{~mL}$ of $96 \%$ analytical methanol. Subsequently, the mixture was homogenized in an ultrasound bath (Branson 2800 ultrasound, USA) for $30 \mathrm{~min}$ at $4{ }^{\circ} \mathrm{C}$ and centrifuged (HERMLE Z326K Centrifuge, Germany) for $30 \mathrm{~min}$ at $25^{\circ} \mathrm{C}$ and $6000 \mathrm{rpm}$. Finally, the supernatant was filtered until the five dilutions were obtained at concentrations of $500 \mu \mathrm{L}$, $600 \mu \mathrm{L}, 700 \mu \mathrm{L}$, and $800 \mu \mathrm{L}$, which were settled in Eppendorf tubes with $96 \%$ methanol up to one milliliter. The antioxidant capacity obtained by the ABTS $\bullet+$ method was obtained by interpolation as the equivalent Trolox amount (TEAC $\mu$ mol Trolox/g extract). In the DPPH $\bullet$ method, we reported the $\mathrm{EC}_{50}$ with each treatment.

\subsection{Statistical Analysis}

The analysis of variance (ANOVA) and the LSD method (minimum significant difference) of multiple comparisons, with a 95\% confidence level $(\alpha=0.05)$, were used to assess the effect of edible coatings on the response variables described previously. The Stat graphics Centurion XVI program was used for these statistical analyzes.

\section{Results and Discussion}

\subsection{Characterization of Emulsions}

The main reasons of using chitosan of medium molecular weight with moderate deacetylation degree (DD) were that it had been proven to have excellent film-forming properties, presenting higher mechanical properties (higher tensile strength) and better barrier properties (better weight loss control, lower water vapor permeability, lower respiration rate, lesser loss of flavor volatiles, and delay of the microbial growth) than those of lower molecular weight [14,36,37].

On the other hand, it is generally accepted that chitosan antimicrobial properties vary depending on the molecular weight and deacetylation degree. Usually, chitosan with lower molecular weight has higher antimicrobial activity than chitosan with high molecular weight $[38,39]$, supposedly due to an increased water solubility that stimulates the reaction with the active sites of the microorganisms [40].

When the antimicrobial activity depends on the polycation water-soluble structure, the increase in the deacetylation degree will improve this activity due to the electrostatic interaction between $\mathrm{NH}^{+}$ groups of chitosan and the phosphoryl groups of the phospholipid component of the cell membrane of the microorganisms [41-43].

However, depending on the microorganism and the composition of its cells, the antimicrobial activity of chitosan can also be due to adsorption on the cell surface, which is also favored by a higher molecular weight (more hydrophobic interactions), especially for Gram-positive bacteria and fungi [44,45].

Thus, we decided to combine the use of a polymer matrix and Rue essential oil, reinforcing the antimicrobial properties, which also allows a reduction of the diffusion rate and higher amounts of the antimicrobial agent on the surface of the fruit. In addition, chitosan in several investigations has been proved to inhibit microbial spoilage in fresh and minimally processed fruits and vegetables [36]. 
The potential of coatings to protect the fruit depends on the properties and stability of their forming emulsions [46]. The properties of the coating will depend on the molecular structure rather than the molecular size or the composition. Good elasticity and flexibility are essential in layers to prevent cracking during handling and storage. Usually, adding plasticizers like glycerol and sorbitol to the emulsion will accomplish this requirement. On the other hand, emulsifiers like tween 80 are added to improve the homogeneity of the hydrocolloid-forming emulsions, improving wettability also suppressing the ripening process without negatively affect the fruit quality [47].

Coatings should be prepared from materials than can solubilize in water and some additives such as plasticizers, antimicrobials, antioxidants, colors, flavors, that improve the quality and the perception of the fruits can be added to the emulsions. The $\mathrm{pH}$ and temperature can be adjusted to facilitate the dispersion of the polymer. For that reason, the $\mathrm{pH}$ of the emulsions was acid in all cases (Table 1). Acid pH will support chitosan dissolution. However, it increased with the essential oil content due probably to the adsorption of the CS chains on the surface of the essential oil drops, decreasing the amount of availability of some hydrogen ions and increasing the $\mathrm{pH}$ of the solutions. It has been recognized that the introduction of essential oil amounts to chitosan emulsions will decrease the overall availability of CS chains and a net charge change as a consequence, which also affects the hydrodynamic volume and zeta potential of the emulsions $[48,49]$.

Table 1. Physical-chemical properties of the chitosan (CS) + Ruta graveolens L. essential oil (RGEO) emulsions.

\begin{tabular}{cccccc}
\hline $\begin{array}{c}\text { Essential Oil } \\
\text { Content (\%) }\end{array}$ & pH & Density (g/mL) & Viscosity (cP) & \% Total Solids & $\begin{array}{c}\text { Particle Size } \\
(\mu \mathrm{m})\end{array}$ \\
\hline 0.0 & $4.36 \pm 0.01^{\mathrm{a}}$ & $1.0018 \pm 0.01^{\mathrm{a}}$ & $124.7 \pm 0.1^{\mathrm{d}}$ & $2.96 \pm 0.02^{\mathrm{a}}$ & N.D. \\
\hline 0.5 & $4.40 \pm 0.01^{\mathrm{b}}$ & $1.0080 \pm 0.01^{\mathrm{b}}$ & $97.3 \pm 0.1^{\mathrm{c}}$ & $3.40 \pm 0.01^{\mathrm{b}}$ & $1.14 \pm 0.25^{\mathrm{b}}$ \\
\hline 1.0 & $4.40 \pm 0.01^{\mathrm{b}}$ & $1.0082 \pm 0.01^{\mathrm{b}}$ & $80.3 \pm 0.1^{\mathrm{b}}$ & $3.51 \pm 0.02^{\mathrm{b}}$ & $1.69 \pm 0.32^{\mathrm{c}}$ \\
\hline 1.5 & $4.44 \pm 0.01^{\mathrm{c}}$ & $1.0088 \pm 0.01^{\mathrm{c}}$ & $26.0 \pm 0.2^{\mathrm{a}}$ & $3.53 \pm 0.02^{\mathrm{b}}$ & $0.86 \pm 0.12^{\mathrm{b}}$ \\
\hline
\end{tabular}

Note: The superscripts $(\mathrm{a}-\mathrm{d})$ in the same column refer to significant differences $(p<0.05)$ between each treatment.

The results obtained from the density analysis of the different emulsions show typical values of diluted emulsions. However, the values significantly increased $(p<0.05)$ with the RGEO content, probably due to the increased concentration of essential oil in the dispersed phase of the emulsion. Similarly, the incorporation of RGEO had a significant effect $(p<0.05)$ on the apparent viscosity. The lower value was obtained in the emulsion with the highest concentration of RGEO $(26.0 \mathrm{cP})$ and the higher value in the chitosan solution $(124.7 \mathrm{cP})$. Emulsion viscosity reduction results from the decrease in the oil-phase agglomeration, increasing the stability of the emulsion. In addition, the lower availability of CS chains, which are adsorbed on the surface of RGEO surfaces, decreases the viscosity of the emulsions [50]. It is expected that the emulsions from essential oils have low viscosities and be economical for a wide-spread application [51].

CS + RGEO emulsions showed higher values in the percentage of soluble solids due to the retention of the oil in the polymer matrix. The oil is retained in the hydrophobic region of the chitosan; therefore, CS chains must be acting as a colloidal protector through van der Waals interactions and hydrogen bonds between hydroxides and amines of the CS and ketones present in the oil. Typically, it is considered that analyzing the particle size of the emulsions allows determining the stability of the emulsion [25]. On the other hand, a smaller particle size could influence the physical and chemical properties such as the viscosity and density of the emulsions, because a higher contact surface would be available that would improve the features [23]. 


\subsection{Physical-Chemical Analysis of Fruits}

After the analysis of the hydrocolloid-based coating emulsions, it is necessary to analyze the behavior of the coating on the fruit surface. Different studies are performed for that goal: changes in color and texture, weight loss, changes in titratable acidity, soluble solids, $\mathrm{pH}$, and sensory properties.

\subsection{1. $\mathrm{pH}$}

The $\mathrm{pH}$ indicates the total acidity of a solution and often increase during postharvest storage as organic acids are consumed in the respiration and metabolic processes. The $\mathrm{pH}$ increased significantly $(p<0.05)$ during the storage time, because of the organic acid consumption during metabolic reactions due to the activity of dehydrogenase enzymes (Table 2) [52]. The statistical analysis indicated significant differences $(p<0.05)$ between the two factors (Days/Treatments).

It can be evidenced that fruits coated with CS (T2) and with CS + R. graveolens L., (T3, T4, and T5) presented a significant difference $(p<0.05)$ concerning the control. In that sense, the T3 treatment produced the most significant delay in $\mathrm{pH}$ increasing during the twelve days of treatment, thus decreasing the ripening effect on the cape gooseberry. This delay in the $\mathrm{pH}$ increasing could be due to a change of respiration of the fruit generating an anaerobic environment because the coatings with essential oils affect the respiration rate [37].

\subsubsection{Total Soluble Solids}

The increase in total soluble solids (TSS) during the fruit ripening period is due to starch hydrolysis or sucrose synthesis [52]. Edible coatings have been reported to reduce increases in TSS content during storage as a result of suppressed respiration [53]. Between $80 \%$ and $90 \%$ of the TSS present in cape gooseberries correspond to sugars (glucose, sucrose, and fructose) [54]. The result can be observed in Table 2. However, increasing TSS also depends on water loss and must be kept in mind.

The multi-range test between the treatments shows that there was a statistically significant difference $(p<0.05)$ for the control, with all the procedures in the cape gooseberries coated with chitosan and Rue essential oil (R.graveolens L.). This result indicates that the use of coatings delays the increase in TSS in the fruit. T3 demonstrates the delay as it was the treatment that maintained higher acidity percentage values, but it was the treatment that obtained lower values of ${ }^{\circ}$ Brix. Accumulation of sugars in the fruit explains the decrease in the acidity percentage.

\subsubsection{Titratable Acidity}

The acidity index is directly related to $\mathrm{pH}$, due to the natural fruit ripening where organic acids are consumed. The decomposition of these acids is used as a respiratory substrate for the synthesis of new compounds, which causes the fruit to become less acidic over time, as shown in Table 2. The barrier properties of the coatings limit the amount of oxygen absorbed by the fruit, consequently reducing respiration and thus decreasing the consumption of organic acids [55].

The multifactorial statistical analysis showed that the factors (Days/Treatment) have an incidence concerning the response variable with a significant difference at a $95 \%$ confidence level. The acidity decreased from day 6 , but it could be a result of the concentration of the organic acids in the media as a result of the water loss. The coated samples had a significantly higher amount of organic acids inside the fruit, as can be seen from the acidity measurements. The multiple test ranges between the treatments show that there was a statistically significant difference $(p<0.05)$ in all the treatments concerning the control. This result demonstrated that the incorporation of the procedures preserves the organic acids inside the fruit, delaying the ripening process, possibly due to the different atmosphere inside the fruit [55]. 
Table 2. Physical-chemical characteristic in P. peruviana with CS + RGEO coatings stored for 12 days at $18 \pm 2{ }^{\circ} \mathrm{C}$. T1 = Control; T2 = CS; T3 = CS + RGEO 0.5\%; $\mathrm{T} 4=\mathrm{CS}+\mathrm{RGEO} 1.0 \%$; T5 = CS + RGEO $1.5 \%$.

\begin{tabular}{|c|c|c|c|c|c|c|c|c|c|c|c|c|c|c|c|c|}
\hline \multirow[t]{2}{*}{ Time } & \multirow{2}{*}{$\begin{array}{c}\text { Treatment } \\
\text { Control }\end{array}$} & \multicolumn{3}{|c|}{$\mathrm{pH}$} & \multicolumn{3}{|c|}{ TA (\% Citric Acid) } & \multicolumn{3}{|c|}{ TSS $\left({ }^{\circ}\right.$ Brix $)$} & \multicolumn{3}{|c|}{ Mature Index (\%) } & \multicolumn{3}{|c|}{ Damage Index (\%) } \\
\hline & & 3.65 & \pm & $0.07^{\mathrm{a}}$ & 2.12 & \pm & $0.09^{a}$ & 13.74 & \pm & $0.29^{a}$ & 6.50 & \pm & $0.32^{a}$ & 1.00 & \pm & $0.00^{\mathrm{a}}$ \\
\hline \multirow{6}{*}{0} & CS & 3.61 & \pm & $0.05^{\mathrm{a}}$ & 2.08 & \pm & $0.07^{\mathrm{a}}$ & 13.57 & \pm & $0.29^{a}$ & 6.53 & \pm & $0.16^{\mathrm{a}}$ & 1.00 & \pm & $0.00^{\mathrm{a}}$ \\
\hline & $\mathrm{CS}+0.5 \% \mathrm{RGEO}$ & 3.64 & \pm & $0.01^{\mathrm{a}}$ & 2.12 & \pm & $0.01^{\mathrm{a}}$ & 13.58 & \pm & $0.29^{a}$ & 6.40 & \pm & $0.10^{\mathrm{a}}$ & 1.00 & \pm & $0.00^{\mathrm{a}}$ \\
\hline & $\mathrm{CS}+1.0 \%$ RGEO & 3.67 & \pm & $0.03^{\mathrm{a}}$ & 2.11 & \pm & $0.09^{\mathrm{a}}$ & 13.74 & \pm & $0.29^{a}$ & 6.53 & \pm & $0.17^{\mathrm{a}}$ & 1.00 & \pm & $0.00^{\mathrm{a}}$ \\
\hline & CS + 1.5\%RGEO & 3.67 & \pm & $0.02^{\mathrm{a}}$ & 2.12 & \pm & $0.03^{\mathrm{a}}$ & 13.58 & \pm & $0.29^{a}$ & 6.40 & \pm & $0.07^{\mathrm{a}}$ & 1.00 & \pm & $0.00^{\mathrm{a}}$ \\
\hline & Control & 3.91 & \pm & $0.04^{\mathrm{c}}$ & 1.73 & \pm & $0.02^{a}$ & 14.17 & \pm & $0.29^{a}$ & 8.19 & \pm & $0.17^{c}$ & 1.00 & \pm & $0.00^{\mathrm{a}}$ \\
\hline & CS & 3.78 & \pm & $0.02^{b}$ & 1.92 & \pm & $0.01^{b}$ & 13.71 & \pm & $0.29^{a}$ & 7.12 & \pm & $0.14^{\mathrm{b}}$ & 1.00 & \pm & $0.00^{\mathrm{a}}$ \\
\hline \multirow[t]{5}{*}{3} & $\mathrm{CS}+0.5 \% \mathrm{RGEO}$ & 3.70 & \pm & $0.05^{\mathrm{a}}$ & 2.15 & \pm & $0.02^{\mathrm{d}}$ & 13.75 & \pm & $0.29^{a}$ & 6.39 & \pm & $0.19^{\mathrm{a}}$ & 1.00 & \pm & $0.00^{\mathrm{a}}$ \\
\hline & $\mathrm{CS}+1.0 \%$ RGEO & 3.73 & \pm & $0.03^{a b}$ & 2.06 & \pm & $0.03^{c}$ & 14.07 & \pm & $0.29^{a}$ & 6.84 & \pm & $0.21^{b}$ & 1.00 & \pm & $0.00^{\mathrm{a}}$ \\
\hline & CS + 1.5\%RGEO & 3.76 & \pm & $0.04^{\mathrm{ab}}$ & 2.03 & \pm & $0.00^{\mathrm{c}}$ & 13.89 & \pm & $0.00^{\mathrm{a}}$ & 6.84 & \pm & $0.00^{b}$ & 1.00 & \pm & $0.00^{\mathrm{a}}$ \\
\hline & Control & 3.96 & \pm & $0.04^{\mathrm{c}}$ & 1.69 & \pm & $0.00^{a}$ & 14.66 & \pm & $0.29^{b}$ & 8.67 & \pm & $0.18^{c}$ & 1.33 & \pm & $0.58^{a}$ \\
\hline & CS & 3.76 & \pm & $0.02^{b}$ & 1.86 & \pm & $0.03^{b}$ & 14.20 & \pm & $0.29 \mathrm{ab}$ & 7.61 & \pm & $0.11^{b}$ & 1.00 & \pm & $0.00^{\mathrm{a}}$ \\
\hline \multirow[t]{5}{*}{6} & $\mathrm{CS}+0.5 \%$ RGEO & 3.76 & \pm & $0.02^{\mathrm{a}}$ & 2.01 & \pm & $0.00^{\mathrm{d}}$ & 14.06 & \pm & $0.29^{\mathrm{a}}$ & 7.00 & \pm & $0.15^{\mathrm{a}}$ & 1.00 & \pm & $0.00^{\mathrm{a}}$ \\
\hline & CS + 1.0\%RGEO & 3.90 & \pm & $0.04^{\mathrm{ab}}$ & 1.92 & \pm & $0.03^{c}$ & 14.37 & \pm & $0.00^{\mathrm{ab}}$ & 7.50 & \pm & $0.10^{\mathrm{b}}$ & 1.00 & \pm & $0.00^{\mathrm{a}}$ \\
\hline & $\mathrm{CS}+1.5 \%$ RGEO & 3.86 & \pm & $0.03^{\mathrm{b}}$ & 1.92 & \pm & $0.05^{c}$ & 14.20 & \pm & $0.29 \mathrm{ab}$ & 7.42 & \pm & $0.12^{b}$ & 1.00 & \pm & $0.00^{\mathrm{a}}$ \\
\hline & Control & 3.97 & \pm & $0.04^{\mathrm{c}}$ & 1.52 & \pm & $0.00^{\mathrm{a}}$ & 14.96 & \pm & $0.29^{\mathrm{ab}}$ & 9.83 & \pm & $0.20^{\mathrm{d}}$ & 2.00 & \pm & $1.00^{\mathrm{a}}$ \\
\hline & $\mathrm{CS}$ & 3.91 & \pm & $0.03 \mathrm{bc}$ & 1.61 & \pm & $0.02^{b}$ & 14.49 & \pm & $0.29 \mathrm{ab}$ & 8.74 & \pm & $0.27^{c}$ & 1.33 & \pm & $0.58^{\mathrm{a}}$ \\
\hline \multirow[t]{5}{*}{9} & $\mathrm{CS}+0.5 \%$ RGEO & 3.83 & \pm & $0.04^{\mathrm{a}}$ & 1.67 & \pm & $0.01^{\mathrm{d}}$ & 14.19 & \pm & $0.29 \mathrm{ab}$ & 7.64 & \pm & $0.19^{\mathrm{a}}$ & 1.67 & \pm & $1.15^{\mathrm{a}}$ \\
\hline & $\mathrm{CS}+1.0 \%$ RGEO & 3.90 & \pm & $0.06^{\mathrm{bc}}$ & 1.56 & \pm & $0.02^{b}$ & 14.66 & \pm & $0.29^{\mathrm{a}}$ & 8.67 & \pm & $0.06^{b c}$ & 1.00 & \pm & $0.00^{\mathrm{a}}$ \\
\hline & $\mathrm{CS}+1.5 \%$ RGEO & 3.84 & \pm & $0.02 \mathrm{ab}$ & 1.66 & \pm & $0.03^{c}$ & 14.67 & \pm & $0.29^{b}$ & 8.35 & \pm & $0.05^{b}$ & 1.33 & \pm & $0.58^{\mathrm{a}}$ \\
\hline & Control & 4.04 & \pm & $0.05^{b}$ & 1.51 & \pm & $0.03^{a}$ & 15.13 & \pm & $0.29 \mathrm{ab}$ & 9.99 & \pm & $0.33^{\mathrm{d}}$ & 2.33 & \pm & $1.53^{\mathrm{a}}$ \\
\hline & CS & 4.00 & \pm & $0.01^{\mathrm{ab}}$ & 1.61 & \pm & $0.09 \mathrm{abc}$ & 14.98 & \pm & $0.29 \mathrm{ab}$ & 9.34 & \pm & $0.54^{b c}$ & 2.00 & \pm & $1.73^{\mathrm{a}}$ \\
\hline \multirow[t]{3}{*}{12} & $\mathrm{CS}+0.5 \%$ RGEO & 3.99 & \pm & $0.01^{\mathrm{ab}}$ & 1.67 & \pm & $0.01^{\mathrm{c}}$ & 14.66 & \pm & $0.29^{a b}$ & 8.76 & \pm & $0.20^{\mathrm{a}}$ & 2.00 & \pm & $1.00^{\mathrm{a}}$ \\
\hline & $\mathrm{CS}+1.0 \%$ RGEO & 3.96 & \pm & $0.01^{\mathrm{a}}$ & 1.56 & \pm & $0.00^{\mathrm{ab}}$ & 14.97 & \pm & $0.29^{\mathrm{a}}$ & 9.61 & \pm & $0.20^{\mathrm{cd}}$ & 1.33 & \pm & $0.58^{a}$ \\
\hline & CS + 1.5\%RGEO & 3.98 & \pm & $0.01^{\mathrm{a}}$ & 1.66 & \pm & $0.09 \mathrm{bc}$ & 14.82 & \pm & $0.50^{\mathrm{b}}$ & 8.94 & \pm & $0.22^{\mathrm{ab}}$ & 1.67 & \pm & $1.15^{\mathrm{a}}$ \\
\hline
\end{tabular}

Note: The superscript letter in the same column $(a-d)$ refers to the significant differences $(p<0.05)$ between each treatment. 


\subsubsection{Maturity Index}

For the mature index (Table 2), it is observed that in a tropical fruit such as cape gooseberry, at a maturity stage of six shows, the higher amount of carbohydrates and the lowest acidity level [28]. Statistical analysis indicates that the maturity index shows significant differences $(p<0.05)$ in the days of storage, and between the treatments. This result suggests that the fruits coated by CS (T2) and CS + RGEO (T3, T4, T5) retarded the ripening process in an RGEO content-dependent manner. The climatic respiratory pattern of cape gooseberry could be the reason, as cape gooseberries quickly unfold their reserves (organic acids) in response to the increase in their metabolism, increasing total soluble solids, and, consequently, the maturity index [56].

\subsubsection{Damage Index}

It is well known that fungal growth on the guavas fruit surface under ambient conditions decreased the quality of the fruits, increasing consumer rejection [23]. The knowledge in the damage caused directly on the fruits allows measuring the impact on production as a preventive measurement. The behavior during the days evaluated is shown in Table 2 .

Despite the multi-range test that did not demonstrate significant $(p<0.05)$ differences between the treatments after twelve days, the microbial analysis showed a higher fungal decay for uncoated fruits as compared to CS + RGEO coated nuts. However, this might be due to the qualitative analysis of the assay and the absence of severe physical damage after twelve days. Nevertheless, Sinning et al. [57] and Grande et al. [23] previously reported that chitosan-based coatings and Rue essential oil in papayas decreased the growth of spoilage molds and improved the damage index.

\subsubsection{Weight Loss Percentage}

Monitoring the weight change during the storage period indicates the effectiveness against moisture of the coating. It is considered that the weight changes in the fruits depend almost exclusively on the water loss since the loss of volatile compounds from the fruits like aroma and flavor molecules and metabolic gas residues are practically undetectable in weight [58]. The results in Figure 2 show weight loss in the fruit. However, the nuts that were coated had a lower weight loss compared to the control fruit (Figure 2).

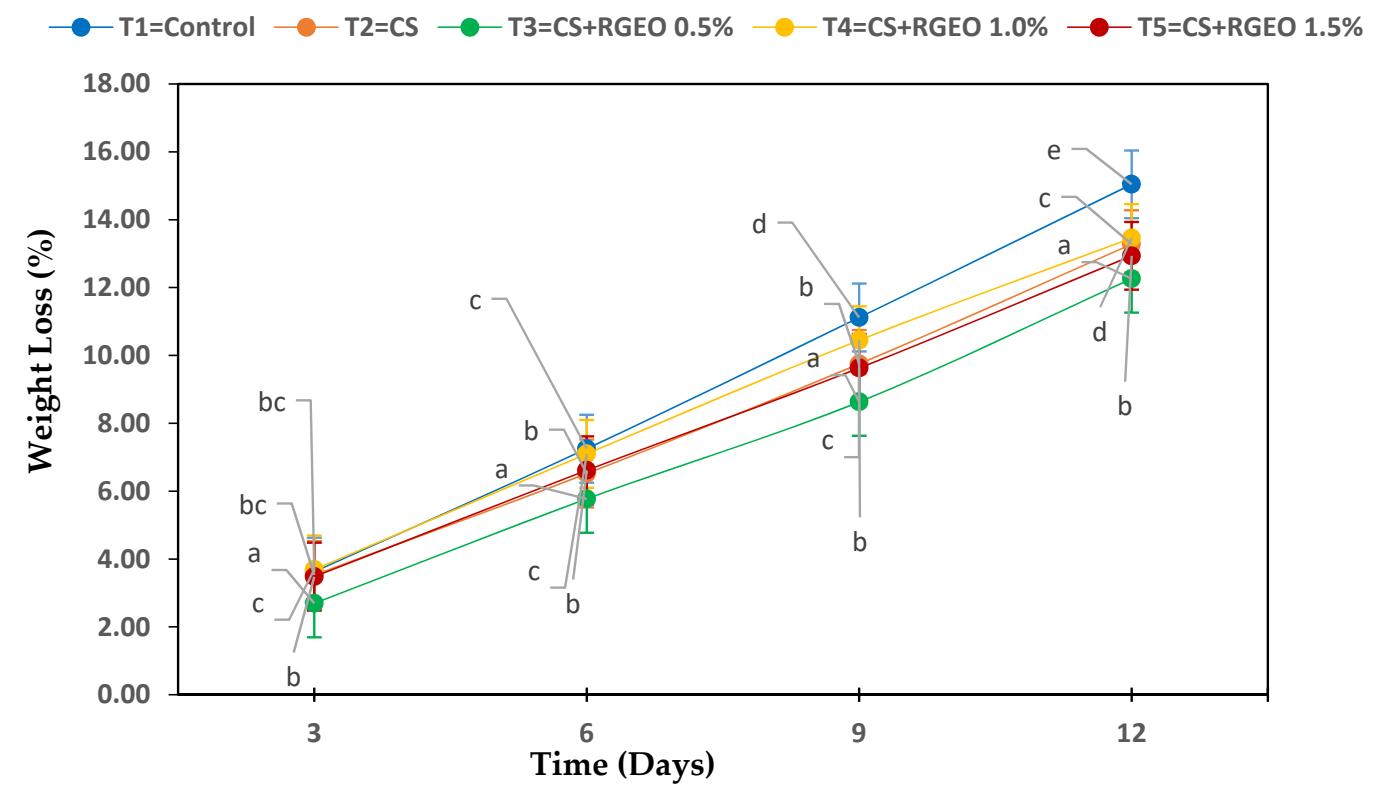

Figure 2. The behavior of the weight loss percentage during the 12 days of evaluation in cape gooseberries coated with the treatments. Note: The superscript letter $(a-d)$ refers to the significant differences $(p<0.05)$ between each treatment. 
The lower weight loss could be explained by the barrier action exerted by chitosan and RGEO against the diffusion of water vapor. When pressure steam of the external environment is lower than that of the internal fruit, it results in a decrease in weight over time, thus causing a reduction in the appearance, firmness, and nutritional quality of the fruit [59]. The multifactorial statistical analysis of type III showed that the factors Days/Treatment $(p<0.05)$, have a statistically significant effect concerning the response variable at a $95 \%$ confidence level. T3 had a considerable difference compared to the control indicating that the incorporation of RGEO has a positive effect concerning this parameter.

\subsubsection{Color Index}

The color of the epidermis fruit is a benchmark of the maturity index [6]. This is due to the chlorophyll degradation starting with the phytol dissociation residue and the porphyrin ring of the chlorophyll molecule. This reaction is catalyzed by an enzyme called chlorophyllase [60]. This reaction allows the color of the fruit to increase its intensity, as shown in Figure 3. We determined the color changes using a colorimeter in the CIE $\mathrm{L}^{*} \mathrm{a}{ }^{*} \mathrm{~b}$ * scale, where $\mathrm{L}$ * indicates lightness and $\mathrm{a}$ * and $\mathrm{b}$ * are the chromaticity coordinates (rectangular coordinates). On the other hand, $+\mathrm{a} *$ is the red direction, $-\mathrm{a}$ $*$ is the green direction, $+b$ * is the yellow direction, and $-b$ * is the blue direction [58].

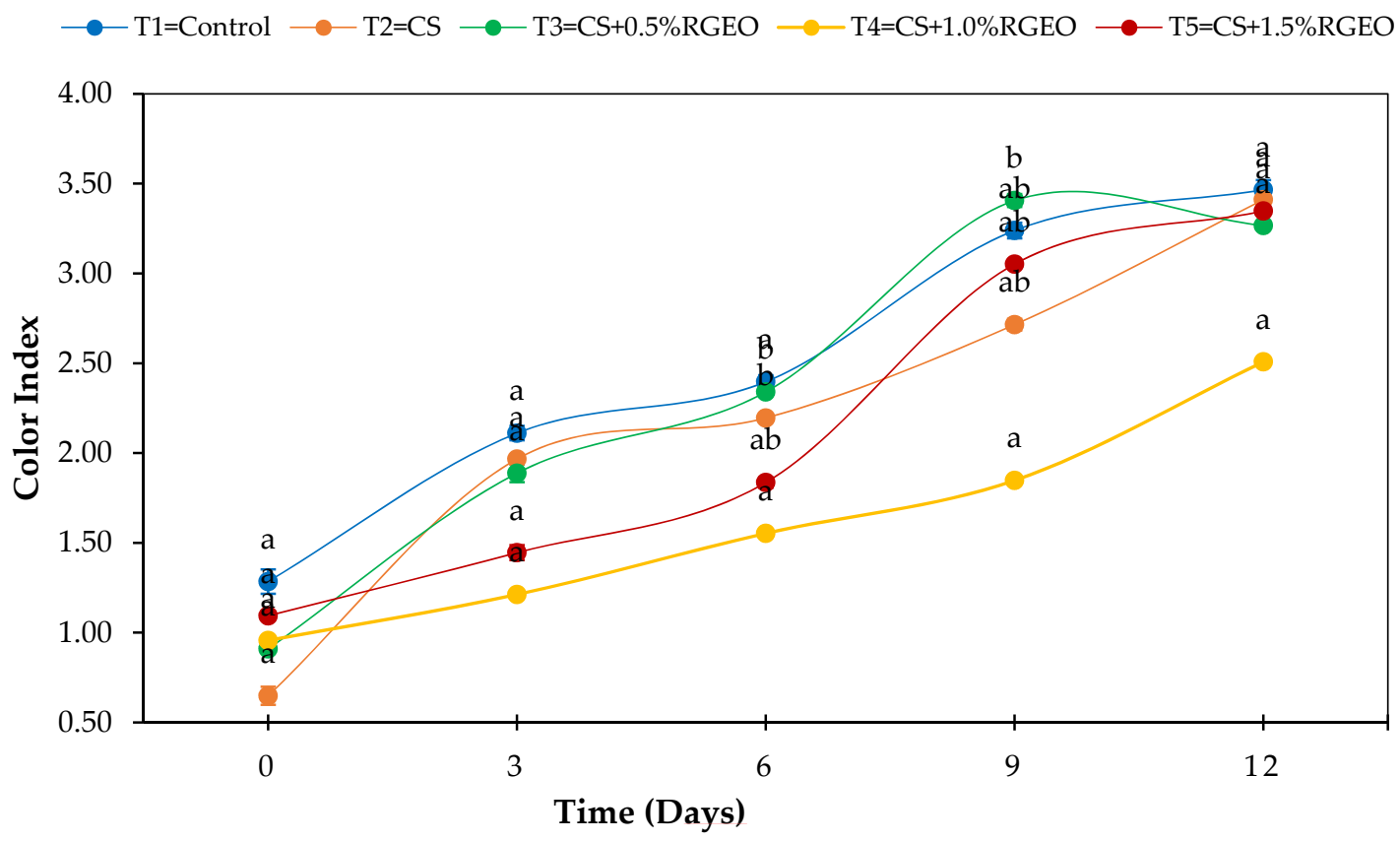

Figure 3. The color index in the fruits of cape gooseberries during the 12 days of storage covered with each treatment. The superscript letter $(\mathrm{a}-\mathrm{d})$ refers to the significant differences $(p<0.05)$ between each treatment.

Figure 3 shows an ascent of this parameter from day 0 to day 12 in all treatments and control, indicating that during the days evaluated the effect of chlorophyll degradation affects the red/green coordinates $\left(\mathrm{a}^{*}\right)$ and the yellow/blue coordinates $\left(\mathrm{b}^{*}\right)$ intensifying their value. These results depend on the postharvest characteristics, and the state of maturity (3-4) due to this it is expected that the color index and the evolution of the carotenoid content are high in this phase [6].

Statistical data show that there was a significant difference $(p<0.05)$ concerning days and treatments. The multiple range test showed that the most significant difference concerning the procedures was for the fruits coated with chitosan and 1.0\%RGEO. An additional analysis of the coatings of CS + RGEO $(0.5 \%, 1.0 \%$, and $1.5 \%)$ showed that in the evaluated color scale, a lower presence of yellow and red tones was observed in comparison with the uncoated samples. Similar results were previously obtained in other researches with chitosan-essential oil coatings [23]. 


\subsection{Microbiological Analysis}

Microbial decay in cape gooseberries fruit is a result of the fungal attack of Penicillium expansum, Botrytis cinerea, Monilinia fructicola, and Rhizopus stolonifer, causing green/blue mold rot, grey mold rot, brown rot, and soft rot, respectively $[10,11]$. Edible coatings have been reported to be very active controlling microbial attack on the fruit surfaces, especially against fungal attack [61-63].

\subsubsection{Aerobic Mesophylls}

The aerobic mesophylls bacterial describe a general group, i.e., the population of bacterial colonies produced an agar-based medium under defined temperature and time of incubation, using organic nutrients for growth [64]. The effect of the application of coatings based on CS + RGEO on cape gooseberry can be studied in Figure 4, with a reduction of aerobic mesophylls on the surface of CS + RGEO coated fruits.
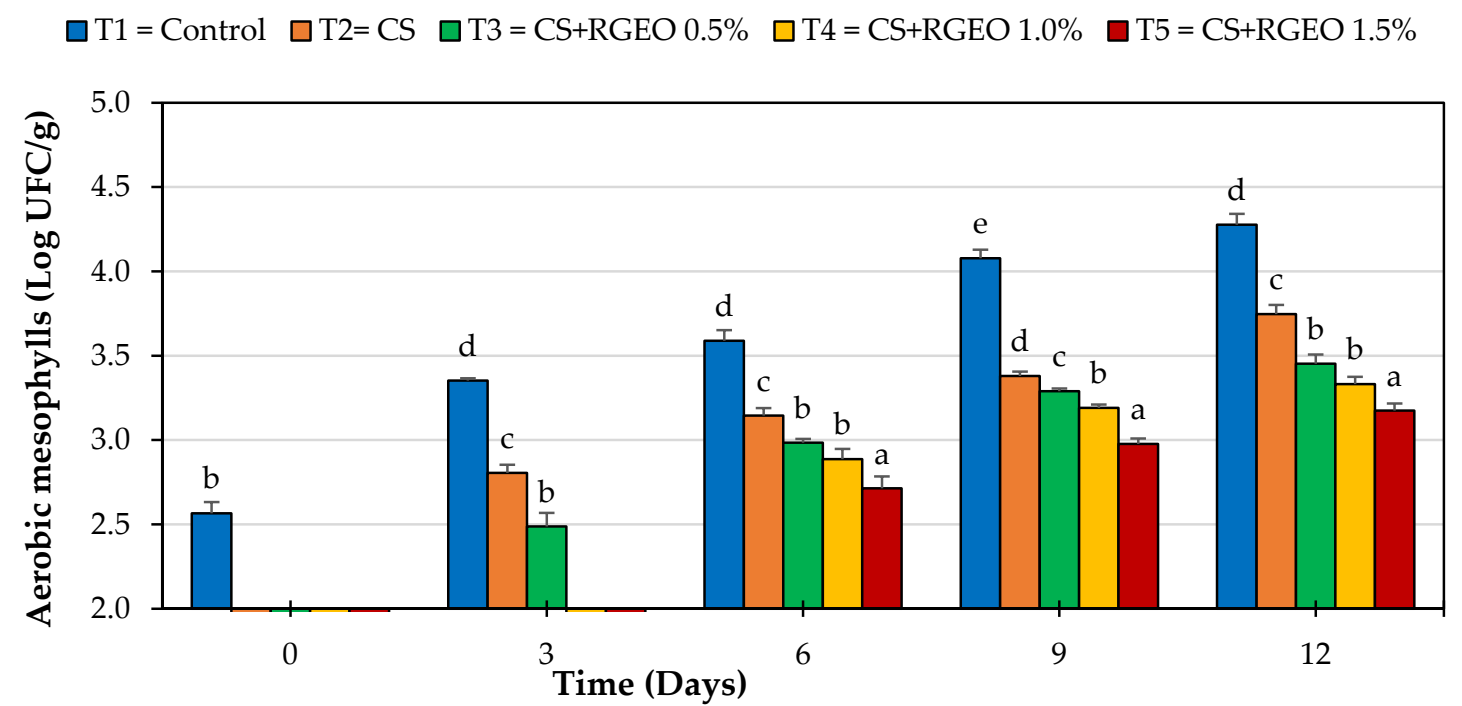

Figure 4. Aerobic mesophylls count for the treatments applied to cape gooseberry. The superscript letter $(\mathrm{a}-\mathrm{d})$ refers to the significant differences $(p<0.05)$ between each treatment.

The statistical analysis showed that there are significant differences $(p<0.05)$ in the days of storage and the treatments concerning the population growth of aerobic mesophylls at a $95 \%$ confidence level. The multi-range test between the treatments shows that there was a statistically significant difference $(p<0.05)$ for the control with all the procedures in the cape gooseberries coated with CS+RGEO. This result indicates that the antibacterial activity of chitosan and RGEO components such as ketones and sesquiterpenoids, support the decreasing of the population by almost two logarithmic units, but did not inhibit bacterial growth, indicating that the coatings only have a retarding activity for bacterial spoilage growth since after day 6, all the treatments had bacterial growth. The effect was directly proportional to the oil content, indicating a synergistic effect as compared to the $\mathrm{T} 2$ treatment.

\subsubsection{Molds and Yeasts}

Figure 5 shows the effect of the CS + RGEO coatings on the growth of fungi and yeasts on the surface of cape gooseberries during the days of storage.

Significant reduction $(p<0.05)$ in the Log CFU/g is observed in the cape gooseberries coated concerning the control. The antifungal activity of CS + RGEO delayed the growth of molds and yeasts during storage. Still, it did not inhibit the growth, because after three days, all the case gooseberries allow fungal and yeast growth (Botrytis cinerea, Cladosporium sp, and some species of Fusarium and Penicillium), probably due to the nature of these fungi [65]. After twelve days of storage, the growth for 
$\mathrm{T} 4$ and $\mathrm{T} 5$ was lower than $3 \log \mathrm{CFU} / \mathrm{g}$. However, uncoated fruits had $4 \mathrm{Log} \mathrm{CFU} / \mathrm{g}$, which demonstrates a control effect on the growth of fungi on the case gooseberry surface.

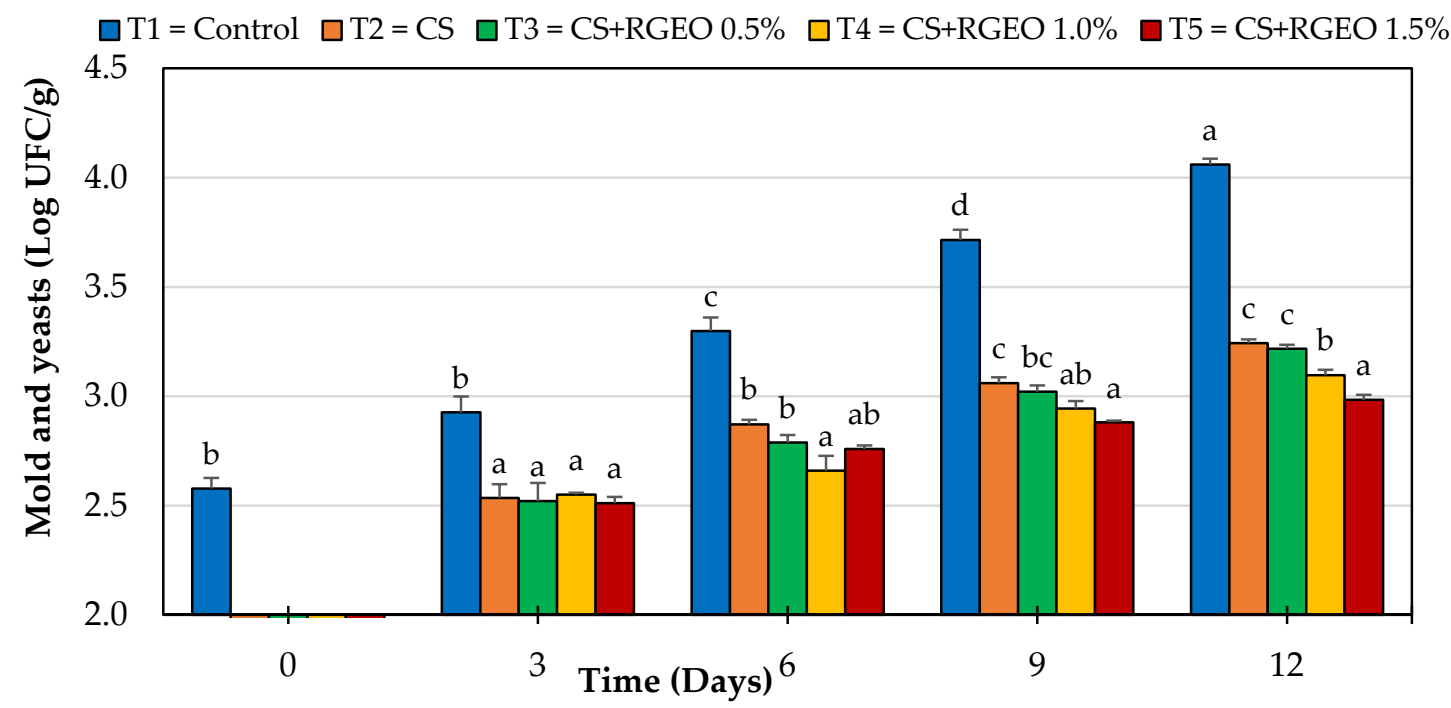

Figure 5. Mold and yeasts count for the treatments applied to cape gooseberry. The superscript letter $(\mathrm{a}-\mathrm{d})$ refers to the significant differences $(p<0.05)$ between each treatment.

Significant differences $(p<0.05)$ between days and treatments concerning the growth of molds and yeasts at a confidence level of $95 \%$ were observed.

The initial count in control cape gooseberries was $2.6 \mathrm{Log}$ UFC/g up to $4.1 \mathrm{Log}$ UFC/g, higher compared to cape goats treated with CS + RGEO that obtained values between 2.9 and $3.2 \mathrm{Log} \mathrm{UFC} / \mathrm{g}$. Previously, it has been demonstrated that chitosan-based coatings are effective in inhibiting cell growth in plums, both when plums were inoculated pre-coating as well as post-coating. Therefore, coatings may be useful in reducing microbial growth regardless of when infection occurred [66].

On the other hand, the sensory analysis allows measuring the quality of the fruit, knowing the acceptance of the products by the consumer. Sensory aspects may include appearance, color, flavor, and texture, which probably remains the most required attribute strongly affecting consumer decision to purchase the product [12]. The results of the sensory analysis represented in a hedonic curve, as seen in Figure 6.

Figure 6 shows the overall acceptability of attributes by days of storage. The treatments that showed lower effects on sensory characteristics were T1 and T2. In contrast, treatments T3, T4, and $\mathrm{T} 5$ were affected in the flavor and aroma attributes by a bitter and robust flavor caused by the essential oil, presenting significant differences in each treatment $(p<0.05)$. However, in the texture and flavor attributes, there were no significant differences after the storage days, which indicates that the characteristics were preserved between days 0 and 6 . It can be determined that the treatments with higher acceptability in the sensory tests were T1 and T2, while low acceptability were treatments with RGEO content. Despite the enormous potential of essential oils, some authors have reported changes in the organoleptic properties of foods when these oils are used, due to their intense aroma and toxicity problems [14]. Based on the sensorial analysis, we recommend the use of T3 (CS + RGEO $0.5 \%$ ) for cape gooseberries protection, which does not affect consumer acceptance drastically but prevents physical-chemical and microbiological decay of fruits. 


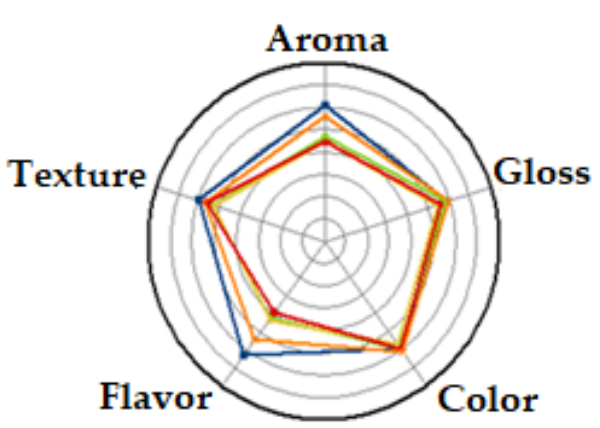

(a)

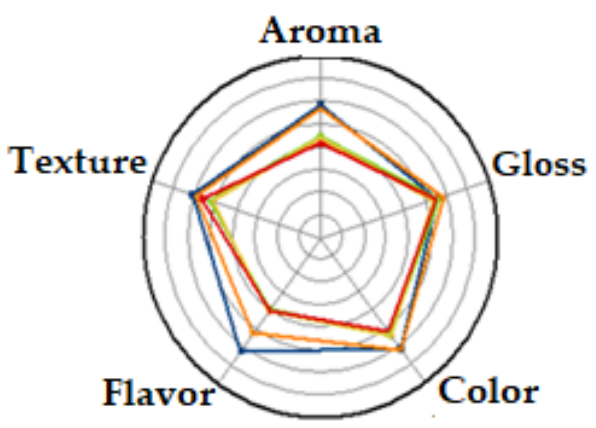

(b)

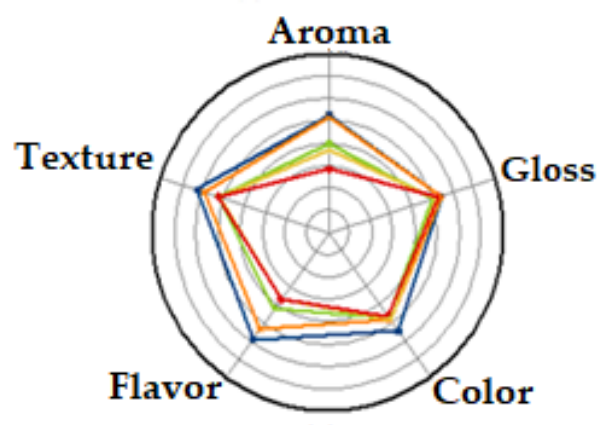

--T1=Control $--\mathrm{T} 2=\mathrm{CS}$

$-\mathrm{T} 3=\mathrm{CS}+\mathrm{RGEO} .5 \%$

T4=CS+RGEO1.0\% --T5=CS+RGEO1.5\% Scale (1.0-9.0)

(c)

Figure 6. The hedonistic scale of the sensory analysis on days 0 (a), 3 (b), and 6 (c).

\subsection{Antioxidant Activity}

The incorporation of antioxidants is widespread in coatings for fresh-cut produce, as discoloration is often a significant challenge [62]. Chitosan-essential oil coatings have been probed to control antioxidant losses in several fruits [14,25].

\subsubsection{DPPH}

2,2'-Diphenyl-1-picrylhydrazyl (DPPH) free radical scavenging method evaluated the antioxidant potential of a compound, an extract, or another biological source, based on the spectrophotometric measurement of DPPH concentration changes resulting from the DPPH reaction with an antioxidant. The amount of remaining DPPH in the examined system is a measure of the antioxidative activity of compounds [66,67]. The results reported in Table 3 were determined based on the best inhibitory concentration, corresponding to $0.22 \mathrm{~g}$ of fruit $/ \mathrm{mL} \mathrm{MeOH}$ in each treatment.

The statistical analysis showed that there are significant differences $(p<0.05)$ in the days, but not in the treatments $(p \geq 0.05)$. On day $12, \mathrm{~T} 4$ and T5 maintain a higher antioxidant activity ( $20 \%$ more) as compared to the control. It is observed that until day 6 , the control samples have good antioxidant activity. However, antioxidant activity decreases with fruit attribute losses and antioxidant consumption, such as phenols and flavonoids. The exposed results are due to a post-harvest treatment in a state of maturation between 3 and 4. Cape goose after harvest is exposed to weight loss and carotenoids and secondary metabolites volatilization or degradation. During day zero, the heterogeneity of the antioxidant activity could be a result of the fruit heterogeneity. However, during the days of treatment, it is possible to see the positive preservation of the antioxidant action on the coated fruits. 
Table 3. Antioxidant capacity expressed as a percentage of inhibition by the 2,2'-azinobis-(3-ethyl-benzothiazoline-6-sulphonic acid) (ABTS) and DPPH methods.

\begin{tabular}{|c|c|c|c|c|c|c|c|}
\hline \multirow[t]{2}{*}{ Day } & \multirow{2}{*}{$\begin{array}{c}\text { Treatment } \\
\text { Control }\end{array}$} & \multicolumn{3}{|c|}{ ABTS (\%) } & \multicolumn{3}{|c|}{ DPPH (\%) } \\
\hline & & 63.79 & \pm & $0.036^{\mathrm{a}}$ & 73.43 & \pm & $0.023^{a b}$ \\
\hline \multirow{4}{*}{0} & $\mathrm{CS}$ & 64.71 & \pm & $0.051^{\mathrm{a}}$ & 81.21 & \pm & $0.029^{a}$ \\
\hline & $\begin{array}{c}\text { CS + } \\
0.5 \% \text { RGEO }\end{array}$ & 61.43 & \pm & $0.018^{a}$ & 64.00 & \pm & $0.113^{a b}$ \\
\hline & $\begin{array}{c}\text { CS + } \\
1.0 \% \text { RGEO }\end{array}$ & 58.57 & \pm & $0.003^{\mathrm{a}}$ & 67.93 & \pm & $0.035^{\mathrm{ab}}$ \\
\hline & $\begin{array}{c}\text { CS + } \\
1.5 \% \text { RGEO }\end{array}$ & 62.57 & \pm & $0.040^{\mathrm{a}}$ & 54.79 & \pm & $0.023^{b}$ \\
\hline \multirow{5}{*}{3} & Control & 51.71 & \pm & $0.010^{a}$ & 51.57 & \pm & $0.081^{\mathrm{a}}$ \\
\hline & CS & 47.50 & \pm & $0.008^{a}$ & 52.07 & \pm & $0.018^{\mathrm{a}}$ \\
\hline & $\begin{array}{c}\text { CS + } \\
0.5 \% \text { RGEO }\end{array}$ & 56.29 & \pm & $0.007^{\mathrm{a}}$ & 55.07 & \pm & $0.090^{\mathrm{a}}$ \\
\hline & $\begin{array}{c}\mathrm{CS}+ \\
1.0 \% \mathrm{RGEO}\end{array}$ & 44.07 & \pm & $0.054^{\mathrm{a}}$ & 56.57 & \pm & $0.014^{\mathrm{a}}$ \\
\hline & $\begin{array}{c}\text { CS + } \\
1.5 \% R G E O\end{array}$ & 51.71 & \pm & $0.059^{a}$ & 61.64 & \pm & $0.009^{a}$ \\
\hline \multirow{5}{*}{6} & Control & 50.07 & \pm & $0.015^{\mathrm{a}}$ & 60.86 & \pm & $0.055^{\mathrm{a}}$ \\
\hline & CS & 52.36 & \pm & $0.025^{\mathrm{a}}$ & 53.86 & \pm & $0.057^{\mathrm{a}}$ \\
\hline & $\begin{array}{c}\text { CS + } \\
0.5 \% \text { RGEO }\end{array}$ & 54.86 & \pm & $0.018^{a}$ & 50.93 & \pm & $0.076^{\mathrm{a}}$ \\
\hline & $\begin{array}{c}\text { CS + } \\
1.0 \% \text { RGEO }\end{array}$ & 51.79 & \pm & $0.011^{\mathrm{a}}$ & 59.07 & \pm & $0.015^{\mathrm{a}}$ \\
\hline & $\begin{array}{c}\mathrm{CS}+ \\
1.5 \% \text { RGEO }\end{array}$ & 53.21 & \pm & $0.026^{\mathrm{a}}$ & 55.64 & \pm & $0.080^{\mathrm{a}}$ \\
\hline \multirow{5}{*}{9} & Control & 54.36 & \pm & $0.004^{\mathrm{a}}$ & 54.07 & \pm & $0.002^{b c}$ \\
\hline & CS & 47.79 & \pm & $0.052^{\mathrm{a}}$ & 57.07 & \pm & $0.017^{b}$ \\
\hline & $\begin{array}{c}\text { CS + } \\
0.5 \% \text { RGEO }\end{array}$ & 58.00 & \pm & $0.004^{\mathrm{a}}$ & 62.50 & \pm & $0.001^{\mathrm{a}}$ \\
\hline & $\begin{array}{c}\mathrm{CS}+ \\
1.0 \% \text { RGEO }\end{array}$ & 49.14 & \pm & $0.023^{a}$ & 50.43 & \pm & $0.004^{\mathrm{c}}$ \\
\hline & $\begin{array}{c}\text { CS + } \\
1.5 \% \text { RGEO }\end{array}$ & 43.79 & \pm & $0.094^{\mathrm{a}}$ & 55.79 & \pm & $0.012^{b}$ \\
\hline \multirow{5}{*}{12} & Control & 17.79 & \pm & $0.002^{d}$ & 23.86 & \pm & $0.003^{\mathrm{d}}$ \\
\hline & $\mathrm{CS}$ & 46.36 & \pm & $0.008^{a}$ & 51.79 & \pm & $0.019^{b}$ \\
\hline & $\begin{array}{c}\text { CS + } \\
0.5 \% \text { RGEO }\end{array}$ & 34.64 & \pm & $0.008^{c}$ & 57.71 & \pm & $0.007^{\mathrm{a}}$ \\
\hline & $\begin{array}{c}\text { CS + } \\
1.0 \% \text { RGEO }\end{array}$ & 41.71 & \pm & $0.010^{b}$ & 49.29 & \pm & $0.010^{b}$ \\
\hline & $\begin{array}{c}\text { CS + } \\
1.5 \% \text { RGEO }\end{array}$ & 44.86 & \pm & $0.021^{a b}$ & 43.36 & \pm & $0.001^{\mathrm{c}}$ \\
\hline
\end{tabular}

Note: the superscript letter in the same column $(\mathrm{a}-\mathrm{d})$ refers to the significant differences $(p<0.05)$ between each treatment.

\subsubsection{ABTS}

The methods that we used here (DPPH and ABTS) to evaluate the antioxidant activity are typically used in the antioxidant evaluation of different foods. Still, it cannot be forgotten that it is more related to radical scavenging. In many cases, this activity does not correspond to the antioxidant activity since different molecules based on their antioxidant activity interfering in the lipid's oxidation or enzymatic browning. ABTS method is based on the reaction between 2,2'-azinobis-(3-ethyl-benzothiazoline-6-sulphonic acid) (ABTS) with a peroxidase (such as metmyoglobin and $\mathrm{H}_{2} \mathrm{O}_{2}$ ), forming a blue-stable radical cation, ABTS+, that absorb at $600 \mathrm{~nm}$ and an antioxidant molecule present in the fluid will suppress this color absorption in a 
concentration-dependent manner [68]. However, we evaluated the capacity of the coatings to decrease the antioxidant capacity loss by two radical scavenging assays which not necessary correlate, since the fruits have different antioxidant molecules such as enzymatic and non-enzymatic antioxidant activity in such a way that several systems (radical scavenger and lipid oxidation inhibitors) should be addressed. Even though both methodologies are fast, easy to reproduce, and are highly used to assess the antioxidant activity of different fruits. The results indicate that the highest antioxidant capacity obtained by the ABTS method as Trolox equivalent (TEAC $\mu$ mol Trolox/g extract) was $7.07 \mu \mathrm{mol}$ Trolox/g extract relative to the treatment with $0.5 \%$ of RGEO (T3). ABTS and DPPH methods could be confirmed as an excellent antioxidant activity. ABTS results demonstrated an antioxidant activity of 7.07 $\mu \mathrm{mol}$ Trolox/g extract and from the DPPH method an EC 50 of $223 \mathrm{~g} / \mathrm{L}$. Previous studies have reported an antioxidant capacity for these methods of $717.49 \mu \mathrm{mol}$ Trolox/g for DPPH and $3.63 \mu \mathrm{mol}$ Trolox/g in ABTS [69].

Additionally, it was determined that $\mathrm{T} 2$ and $\mathrm{T} 5$ antioxidant capacity from day one to day twelve only decreases from $65 \%$ to $46 \%$ and $55 \%$ to $44 \%$, respectively, while the uncoated fruits (T1) the antioxidant capacity reduced from $65 \%$ to $18 \%$. The above demonstrates a positive effect on the antioxidant activity preservation by the CS + RGEO treatments. Statistical data show that there is a significant difference $(p<0.05)$ in the procedures.

\section{Conclusions}

The incorporation of Ruta graveolens L. essential oil in the chitosan edible coatings allowed to obtain stable emulsions of low viscosity, small particle size, and secure adhesion on the gooseberry surfaces. The application of the treatments in the fruits improved the physical-chemical stability, preventing the consumption of organic acids as reflected by the results in the titratable acidity, $\mathrm{pH}$, maturity index, and weight loss studies.

Microbiological analysis showed a decrease in the population of microorganisms, due to the antimicrobial and antifungal characteristics of the components. CS + RGEO 1.5\% (T5) presented the highest reduction in the colony-forming units concerning the control.

Despite the low acceptance in the sensory analysis of $\mathrm{T} 4$ and $\mathrm{T} 5$, we recommend $\mathrm{T} 3$ as a suitable treatment for cape gooseberry fruits from the physical-chemical preservation results as well as the reasonable microbial spoilage control.

The CS + RGEO coating applications also preserve the antioxidant property of case gooseberries after twelve days of treatment under storage according to the DPPH and ABTS results. Several studies are currently conducted to encapsulate the RGEO for edible coating applications to decrease the aroma and flavor on the coatings and improve consumer acceptance. All the results in the present study demonstrated the positive effect of the implementation of CS + RGEO edible coatings on the physical-chemical, antioxidant, and microbial decay of Physalis peruviana. They could be promising candidate treatment for the food industry.

Author Contributions: Conceptualization, C.D.G.T.; investigation, M.G.-L., Y.M.P., and C.D.G.T.; methodology, M.G.-L., Y.M.P., E.F.L., A.A., and C.D.G.T.; writing—original draft, M.G.-L., Y.M.P., and C.D.G.T.; writing-review and editing, E.F.L., A.A., and C.D.G.T. All authors have read and agreed to the published version of the manuscript.

Funding: This research did not receive external funding.

Conflicts of Interest: The authors declare no conflicts of interest.

\section{References}

1. Strik, B.C. Berry Crops: Worldwide Area and Production Systems. In Berry Fruit Value Added Products for Health Promotion, 1st ed.; Zhao, Y., Ed.; CRC: Boca Raton, FL, USA, 2007; Volume 1, pp. 3-49.

2. Fischer, G.; Herrera, A.; Almanza, P.J. Cape gooseberry (Physalis peruviana L.). In Postharvest Biology and Technology of Tropical and Subtropical Fruits; Elsevier: Amsterdam, The Netherlands, 2011; pp. 374-397. 
3. Ramadan, M.F. Bioactive phytochemicals, nutritional value, and functional properties of cape gooseberry (Physalis peruviana): An overview. Food Res. Int. 2011, 44, 1830-1836. [CrossRef]

4. Mayorga, H.; Knapp, H.; Winterhalter, P.; Duque, C. Glycosidically bound flavor compounds of cape gooseberry (Physalis peruviana L.). J. Agric. Food Chem. 2001, 49, 1904-1908. [CrossRef]

5. McCain, R. Goldenberry, passionfruit and white sapote: Potential fruits for cool subtropical areas. New Crop. 1993, 479-486.

6. Carvalho, C.P.; Villaño, D.; Moreno, D.A.; Serrano, M.; Valero, D. Alginate Edible Coating And Cold Storage For Improving The Physicochemical Quality Of Cape Gooseberry (Physalis Peruviana L.). HSOA J. Food Sci. Nutr. 2015, 1, 1-7. [CrossRef]

7. Flóres, R.; Víctor, J.; Fischer, G.; Sora, R.; Ángel, D. Producción, Poscosecha y Exportación de la Uchuva (Physalis peruviana L.); Universidad Nacional de Colombia: Bogotá, Colombia, 2000; pp. 9-22.

8. Villamizar, F.; Ramírez, A.; Meneses, M. Estudio de la caracterización física, morfológica y fisiológica poscosecha de la uchuva (Physalis peruviana L.). Agro Desarro. 1993, 4, 305-320.

9. Trinchero, G.D.; Sozzi, G.O.; Cerri, A.M.; Vilella, F.; Fraschina, A.A. Ripening-related changes in ethylene production, respiration rate and cell-wall enzyme activity in goldenberry (Physalis peruviana L.), a solanaceous species. Postharvest Biol. Technol. 1999, 16, 139-145. [CrossRef]

10. Rao, V.G. A new post-harvest disease of cape-gooseberry. J. Univ. Bombay 1976, 45, 58-61.

11. Sharma, N.; Khan, A.M. Fruit rots of cape gooseberry. Indian Phytopathol. 1978, 31, 513-514.

12. Ahmad, M.S.; Siddiqui, M.W. Commercial Quality of Fruits: Part I. In Postharvest Quality Assurance of Fruits; Springer: Berlin, Germany, 2015; pp. 61-89.

13. Palou, L.; Smilanick, J.L.; Crisosto, C.H. Evaluation of food additives as alternative or complementary chemicals To conventional fungicides for the control of major postharvest diseases of stone fruit. J. Food Prot. 2009, 72, 1037-1046. [CrossRef]

14. Grande-Tovar, C.D.; Chaves-Lopez, C.; Serio, A.; Rossi, C.; Paparella, A. Chitosan coatings enriched with essential oils: Effects on fungi involved in fruit decay and mechanisms of action. Trends Food Sci. Technol. 2018, 78, 61-71. [CrossRef]

15. Guilbert, S.; Gontard, N.; Gorris, L.G.M. Prolongation of the shelf-life of perishable food products using biodegradable films and coatings. LWT Food Sci. Technol. 1996, 29, 10-17. [CrossRef]

16. Yousuf, B.; Qadri, O.S.; Srivastava, A.K. Recent developments in shelf-life extension of fresh-cut fruits and vegetables by application of different edible coatings: A review. LWT 2018, 89, 198-209. [CrossRef]

17. Kerch, G. Chitosan films and coatings prevent losses of fresh fruit nutritional quality: A review. Trends Food Sci. Technol. 2015, 46, 159-166. [CrossRef]

18. Elsabee, M.Z.; Abdou, E.S. Chitosan based edible films and coatings: A review. Mater. Sci. Eng. C 2013, 33, 1819-1841. [CrossRef] [PubMed]

19. Rojas-Graü, M.A.; Soliva-Fortuny, R.; Martín-Belloso, O. Edible coatings to incorporate active ingredients to fresh-cut fruits: A review. Trends Food Sci. Technol. 2009, 20, 438-447. [CrossRef]

20. Licodiedoff, S.; Koslowski, L.A.D.; Scartazzini, L.; Monteiro, A.R.; Ninow, J.L.; Borges, C.D. Conservation of physalis by edible coating of gelatin and calcium chloride. Int. Food Res. J. 2016, 23.

21. Reddy, D.N.; Al-Rajab, A.J. Chemical composition, antibacterial and antifungal activities of Ruta graveolens L. volatile oils. Cogent Chem. 2016, 2, 1220055. [CrossRef]

22. Kunicka-Styczyńska, A.; Gibka, J. Antimicrobial Activity of Undecan-x-ones (x=2-4). Pol. Tow. Mikrobiol. POLISH Soc. Microbiol. 2010, 59, 301-306. [CrossRef]

23. Grande Tovar, C.D.; Delgado-Ospina, J.; Navia Porras, D.P.; Peralta-Ruiz, Y.; Cordero, A.P.; Castro, J.I.; Valencia, C.; Noé, M.; Mina, J.H.; Chaves López, C. Colletotrichum Gloesporioides Inhibition In Situ by Chitosan-Ruta graveolens Essential Oil Coatings: Effect on Microbiological, Physicochemical, and Organoleptic Properties of Guava (Psidium guajava L.) during Room Temperature Storage. Biomolecules 2019, 9, 399. [CrossRef]

24. Instituto Colombiano de Normas Técnicas y Certificación. Frutas Frescas. Uchuva. Especificaciones; NTC 4580; ICONTEC: Bogotá, Colombia, 1999; Volume 14.

25. Martínez, K.; Ortiz, M.; Albis, A.; Gilma Gutiérrez Castañeda, C.; Valencia, E.M.; Grande Tovar, D.C. The Effect of Edible Chitosan Coatings Incorporated with Thymus capitatus Essential Oil on the Shelf-Life of Strawberry (Fragaria $x$ ananassa) during Cold Storage. Biomolecules 2018, 8, 155. [CrossRef]

26. International Standards Organization. Piston-Operated Volumetric Apparatus-Part-2: Piston Pipettes; ISO: Geneva, Switzerland, 2002; Volume 11. 
27. Bakkali, F.; Averbeck, S.; Averbeck, D.; Idaomar, M. Biological effects of essential oils-A review. Food Chem. Toxicol. 2008, 46, 446-475. [CrossRef] [PubMed]

28. Lanchero, O.; Velandia, G.; Fischer, G.; Varela, N.C.; García, H. Comportamiento de la uchuva (Physalis peruviana L.) en poscosecha bajo condiciones de atmósfera modificada activa. Rev. Corpoica-Ciencia y Tecnol. Agropecu. 2007, 8, 61-68. [CrossRef]

29. Ávila, J.A.; Moreno, P.; Fischer, G.; Miranda, D. Influencia de la madurez del fruto y del secado del cáliz en uchuva (Physalis peruviana L.), almacenada a $18{ }^{\circ} \mathrm{C}$. Acta Agronómica 2006, 55, 29-38.

30. Velez, C.; Alicia, B. Efecto de la radiación UV-C Sobre el Desarrollo de Rhizopus spp. y Phytophthora spp. en la Naranjilla (Solanum quitoense). Bachelor's Thesis, Universidad Tecnológica Equinoccial, Quito, Ecuador, 2012.

31. Balaguera-López, H.E.; Martínez, C.A.; Herrera-Arévalo, A. Papel del cáliz en el comportamiento poscosecha de frutos de uchuva (Physalis peruviana L.) ecotipo Colombia. Rev. Colomb. Ciencias Hortícolas 2014, 8, 181-191. [CrossRef]

32. Instituto Colombiano de Normas Técnicas y Certificación. Microbiología. Guía General para el Recuento de Mohos y Levaduras. In Técnica de Recuento de Colonias a $25^{\circ} \mathrm{C}$; NTC 4132; ICONTEC: Bogotá, Colombia, 1997; Volume 7.

33. Instituto Colombiano de Normas Técnicas y Certificación. Microbiología de Alimentos y Productos para Alimentación Animal. In Requisitos Generales y Directrices para Análisis Microbiológicos; NTC 4092; ICONTEC: Bogotá, Colombia, 2016; Volume 95.

34. International Standard Organization. Microbiology of the Food Chain-Horizontal Method for the Detection and Enumeration of Listeria Monocytogenes and of Listeria spp.-Part 2: Enumeration; ISO: Geneva, Switzerland, 2013; Volume 12.

35. Instituto Colombiano de Normas Técnicas y Certificación. Análisis Sensorial. In Identificación y Selección de Descriptores para Establecer un Perfil Sensorial por una Aproximación Multidimensional; NTC 3932; ICONTEC: Bogotá, Colombia, 1996; Volume 31.

36. Azeredo, H.; de Britto, D.; Assis, O. Chitosan Edible Films and Coatings: A review. In Chitosan: Manufacture, Properties, and Usage; Davis, S.P., Ed.; Nova Science Publishers: Hauppage. NY, USA, 2010; pp. 179-194.

37. Sánchez-González, L.; Pastor, C.; Vargas, M.; Chiralt, A.; González-Martínez, C.; Cháfer, M. Effect of hydroxypropylmethylcellulose and chitosan coatings with and without bergamot essential oil on quality and safety of cold-stored grapes. Postharvest Biol. Technol. 2011, 60, 57-63. [CrossRef]

38. Liu, N.; Chen, X.-G.; Park, H.-J.; Liu, C.-G.; Liu, C.-S.; Meng, X.-H.; Yu, L.-J. Effect of MW and concentration of chitosan on antibacterial activity of Escherichia coli. Carbohydr. Polym. 2006, 64, 60-65. [CrossRef]

39. Dutta, P.K.; Tripathi, S.; Mehrotra, G.K.; Dutta, J. Perspectives for chitosan based antimicrobial films in food applications. Food Chem. 2009, 114, 1173-1182. [CrossRef]

40. Aider, M. Chitosan application for active bio-based films production and potential in the food industry: Review. LWT Food Sci. Technol. 2010, 43, 837-842. [CrossRef]

41. Kim, K.W.; Thomas, R.L.; Lee, C.; Park, H.J. Antimicrobial activity of native chitosan, degraded chitosan, and O-carboxymethylated chitosan. J. Food Prot. 2003, 66, 1495-1498. [CrossRef]

42. Tsai, G.; Su, W.; Chen, H.; Pan, C. Antimicrobial activity of shrimp chitin and chitosan from different treatments and applications of fish preservation. Fish. Sci. 2002, 68, 170-177. [CrossRef]

43. Liu, H.; Du, Y.; Wang, X.; Sun, L. Chitosan kills bacteria through cell membrane damage. Int. J. Food Microbiol. 2004, 95, 147-155. [CrossRef] [PubMed]

44. Je, J.-Y.; Kim, S.-K.; Byun, H.-G.; Moon, S.-H. Antimicrobial Activity of Hetero-Chitosans and Their Oligosaccharides withDifferent Molecular Weights. J. Microbiol. Biotechnol. 2004, 14, 317-323.

45. Qin, C.; Li, H.; Xiao, Q.; Liu, Y.; Zhu, J.; Du, Y. Water-solubility of chitosan and its antimicrobial activity. Carbohydr. Polym. 2006, 63, 367-374. [CrossRef]

46. Navarro-Tarazaga, M.L. Efecto de la Composición de Recubrimientos Comestibles a Base de Hidroxipropilmetilcelulosa y Cera de Abeja en la Calidad de Ciruelas, Naranjas y Mandarinas. Ph.D. Thesis, Universitat Politècnica de València, Valencia, Spain, 2008.

47. Hernandez, E. Edible coating from lipids and resins. In Edible Coatings and Films to Improve Food Quality; Technomic Publishing: Lancaster, PA, USA; Basel, Switzerland, 1994; pp. 279-303.

48. Bonilla Lagos, M.J.; Atarés Huerta, L.M.; Vargas, M.; Chiralt, A. Physicochemical properties of chitosan-essential oils film-forming dispersions. Effect of homogenization treatments. Procedia Food Sci. 2011, 1, 44-49. [CrossRef] 
49. Vargas, M.; Albors, A.; Chiralt, A.; González-Martínez, C. Characterization of chitosan-oleic acid composite films. Food Hydrocoll. 2009, 23, 536-547. [CrossRef]

50. Bonilla, J.; Atarés, L.; Vargas, M.; Chiralt, A. Effect of essential oils and homogenization conditions on properties of chitosan-based films. Food Hydrocoll. 2012, 26, 9-16. [CrossRef]

51. Dhall, R.K. Advances in edible coatings for fresh fruits and vegetables: A review. Crit. Rev. Food Sci. Nutr. 2013, 53, 435-450. [CrossRef]

52. Álvarez-Herrera, J.G.; Galvis, J.A.; Balaguera-López, H.E. Determinación de cambios físicos y químicos durante la maduración de frutos de champa (Campomanesia lineatifolia R. \& P.). Agron. Colomb. 2009, 27, 253-259.

53. Mahfoudhi, N.; Hamdi, S. Use of Almond Gum and Gum Arabic as Novel Edible Coating to Delay Postharvest Ripening and to Maintain Sweet Cherry (P runus avium) Quality during Storage. J. Food Process. Preserv. 2015, 39, 1499-1508. [CrossRef]

54. Galvis, J.A.; Fischer, G.; Gordillo, O.P. Cosecha y poscosecha de la uchuva. In Avances en Cultivo, Poscosecha y Exportación de la Uchuva; Universidad Nacional de Colombia: Bogotá, Colombia, 2005; pp. 165-190.

55. Hazrati, S.; Kashkooli, A.B.; Habibzadeh, F.; Tahmasebi-Sarvestani, Z.; Sadeghi, A.R. Evaluation of Aloe vera gel as an alternative edible coating for peach fruits during cold storage period. Gesunde Pflanz. 2017, 69, 131-137. [CrossRef]

56. Perdones, A.; Sánchez-González, L.; Chiralt, A.; Vargas, M. Effect of chitosan-lemon essential oil coatings on storage-keeping quality of strawberry. Postharvest Biol. Technol. 2012, 70, 32-41. [CrossRef]

57. Sinning, A.; Bermont, D. Efecto de Recubrimientos Basados en Quitosano y Aceite Esencial de Ruda (Ruta graveolens L.) en el Control de Antracnosis Causada por Colletotrichum Gloeosporioides en Papaya maradol (Carica papaya L.). Bachelor's Thesis, Universidad del Atlántico, Puerto Colombia, Colombia, 2019.

58. Olivas, G.I.; Barbosa-Cánovas, G.V. Edible coatings for fresh-cut fruits. Crit. Rev. Food Sci. Nutr. 2005, 45, 657-670. [CrossRef] [PubMed]

59. Álvarez Quintero, R.M. Formulación de un Recubrimiento Comestible para Frutas Cítricas, Estudio de su Impacto Mediante Aproximación Metabolómica y Evaluación de la Calidad Poscosecha. Ph.D. Thesis, Universidad de Antioquia, Medellin, Colombia, 2012.

60. Kariola, T.; Brader, G.; Li, J.; Palva, E.T. Chlorophyllase 1, a Damage Control Enzyme, Affects the Balance between Defense Pathways in Plants. Plant Cell 2005, 17, 282-294. [CrossRef] [PubMed]

61. Andrade, S.C.A.; Baretto, T.A.; Arcanjo, N.M.O.; Madruga, M.S.; Meireles, B.; Cordeiro, Â.M.T.; Barbosa de Lima, M.A.; de Souza, E.L.; Magnani, M. Control of Rhizopus soft rot and quality responses in plums (Prunus domestica L.) coated with gum arabic, oregano and rosemary essential oils. J. Food Process. Preserv. 2017, 41, e13251. [CrossRef]

62. Riva, S.C.; Opara, U.O.; Fawole, O.A. Recent developments on postharvest application of edible coatings on stone fruit: A review. Sci. Hortic. (Amst.) 2020, 262, 109074. [CrossRef]

63. Ncama, K.; Magwaza, L.S.; Mditshwa, A.; Tesfay, S.Z. Plant-based edible coatings for managing postharvest quality of fresh horticultural produce: A review. Food Packag. Shelf Life 2018, 16, 157-167. [CrossRef]

64. Allen, M.J.; Edberg, S.C.; Reasoner, D.J. Heterotrophic plate count bacteria-What is their significance in drinking water? Int. J. Food Microbiol. 2004, 92, 265-274. [CrossRef]

65. de La-Rotta, M.F. Enfermedades de la uchuva (Physalis peruviana L.); Centro de Edafología y Biología Aplicada del Segura: Murcia, España, 2014; p. 49.

66. Kim, I.; Lee, H.; Kim, J.E.; Song, K.B.; Lee, Y.S.; Chung, D.S.; Min, S.C. Plum coatings of lemongrass oil-incorporating carnauba wax-based nanoemulsion. J. Food Sci. 2013, 78, E1551-E1559. [CrossRef]

67. Dawidowicz, A.L.; Wianowska, D.; Olszowy, M. On practical problems in estimation of antioxidant activity of compounds by DPPH method (Problems in estimation of antioxidant activity). Food Chem. 2012, 131, 1037-1043. [CrossRef]

68. Moharram, H.A.; Youssef, M.M. Methods for determining the antioxidant activity: A review. Alex. J. Fd. Sci. Technol. 2014, 11, 31-42.

69. Ruiz Andrade, E.D. Comparación de Métodos de Análisis para la Determinación de Capacidad Antioxidante en Uvilla (Physalis peruviana). Bachelor's Thesis, Universidad Tecnológica Equinoccial, Quito, Ecuador, 2018.

(C) 2020 by the authors. Licensee MDPI, Basel, Switzerland. This article is an open access article distributed under the terms and conditions of the Creative Commons Attribution (CC BY) license (http://creativecommons.org/licenses/by/4.0/). 